\title{
スペースホルダー法による多孔質チタニウムの作成とその評価
}

\author{
清水 透社 1 , 松崎 邦男的 1 , 尾原 佳伸的 2 \\ か1 産業技術総合研究所 先進製造プロセス研究部門，テ305-8564つくば市並木1-2つくば東事業所. \\ 称積水化成品工業(侏), 广 632-0001 天理市森本町 670.
}

\section{Process of Porous Titanium Using a Space Holder}

\author{
Toru Shimizu ${ }^{\text {th } 1}$, Kunio Matsuzaki ${ }^{\text {th } 1}$ and Yoshinobu Ohara ${ }^{\text {th } 2}$ \\ ${ }^{2}$ National Institute of Advanced Industrial Science and Technology, 1-2 Namiki, Tsukuba 305-8564. \\ ${ }^{2}$ Sekisui Plastic Co.,Ltd., 670 Morimoto-cho, Tenri 632-0001.
}

Received September 22, 2005

\section{SYNOPSIS}

The process of preparing porous metal foam titanium powder has been developed In this process, polystyrene foam powder is used as a space holder, and a water solution of polymer is used as a binder. The slurry of the titanium powder, space holder and binder is added to the gelatinizing agent to increase its viscosity. It can then be formed by hand like clay. The slurry is dried, sintered and porous titanium is obtained. The binder and space holder are decomposed in a heating process before sintering. Using this process, porous titanium with porosity in the range of $17-77 \%$ is produced, and the mechanical properties are evaluated. From these results, porous titanium that has a porosity of 50 to $60 \%$ has a strength of about $30-100 \mathrm{MPa}$ and Young's modulus about $10-30 \mathrm{GPa}$. These mechanical properties arc appropriate for use as implant bone.

\section{KEY WORDS}

Porous titanium, metal foam, biocompatibility, mechanical properties, Young's modulus

\section{1 はじめに}

多孔質あるいは発泡金属は，軽量であると同時に断熱性， 吸音性，衝撃吸収特性にすぐれており，軽量性と耐熱，断熱 性あるいは吸音性が同時に要求される構造材料, さらには衝 撃材料としての応用が検討されている.また，流体の透過性 と比表面積の大きさからフィルター素材, 触媒担体, 電池電 極などへの利用が注目されている ${ }^{1,2)}$.このような, 高気孔率 の多孔質金属の作製手法として, 従来から様々な方法が提案 されているが, 我々は特に金属粉末と水溶性バインダーのス ラリーからの製造方法に注目し,この手法加らの発泡金属作 製手法を開発している3,4

一方, 高気孔率の多孔質金属の利用分野として, 近年, 生 体材料分野への応用が注目されている.特に，チタニウムお よびその合金は優れた対腐食性と生体適合性を持ち ${ }^{5, の), そ の ~}$ 多孔質体は体液の流動と骨細胞の成長が可能であるため注目 されているわ。また，現在使用されている金属製インプラン 卜は骨と比較してヤング率と強度が高く，そのためインプラ ント材周囲の骨の粗髹化を引き起こすことが知られている.
そのような粗髻化を防止する上でインプラント材料として 骨と同程度のヤング率 $(25 \mathrm{GPa})$, および強度 $(110 \sim 180 \mathrm{MPa})$ を持つ材料が適当である ${ }^{8}$. 多孔質材料においてはその気孔 率を調節することにより, ヤング率, 強度の調節が可能であ ることから，このような生体適合を目指した多孔質チタニウ ム素材の粉体からの作製が様々試みられている。

粉体からの製造方法として，そのまま圧縮，㜔結する方法， あるいは気孔を保持するスペースホルダーとして水酸化アン モニウム粉末を添加し焼結する方法などが提案され，試作が 行われている ${ }^{9-13)}$. しかし，その機械的特性の評価は圧縮試 験による場合が多く,ヤング率の評価もほとんど圧縮試験に より行われている.

そこで,ここでは金属粉末とポリマー水溶液のスラリーか らの多孔質体作製方法として,ポリスチレンフォームの粉末 をスペースホルダーとする手法を選択し, 気孔率17〜77\%の 多孔質チタニウムの作製を試みた。ささらに，圧縮，および引 張試験からヤング率, 強度の比較をおこない, 生体材料とし て適当な気孔率を推定した。 
また, ここで試みた手法では, スラリーにゲル化剂を添加 することによって, 粘土のように成形作業に適当な粘性を持 たせている.このことによりスラリーは粘土のように自在に 成形が可能となり，手作業あるいは型取りにより必要な形状 に成形し，乾燥，焼結することによって任意形状のチタニウ ム多孔質体の作製が可能である，そのため，ここで提案する 手法により多孔質化と同時にネットシェイプ化も実現した.

\section{2 開発した多孔質金属作製手法}

2.1 作製手法の概要

ここでの手法ではバインダーとして，ポリビニールアル コール (PVA)の水溶液を使用した. PVA 水溶液は興味深い 様々な特徵を持つが，特に凍結，解凍することにより強固な ゲルとなる ${ }^{14)}$ ，あるいは，嗍砂等のゲル化剂を添加すること により非常に粘ちゅうで可塑性を持つゲルとなる ${ }^{15)}$ ，などの 特徽がある。

ここでは, スラリーに硼砂を添加することによってゲル化 し，任意に成形が可能な粘土状体にする．このようなPVAと して, 洗濯のりとして一般に市販されているゴーセノール (日本合成化学)PVA8 mass\% 溶液を 6 mass\% に希釈して使用 した. 嗍砂には四ほう酸ナトリウム水和物 $\left(\mathrm{Na}_{2} \mathrm{~B}_{4} \mathrm{O}_{7} \cdot 10 \mathrm{H}_{2} \mathrm{O}\right.$, 和光純薬)を使用した. チタニウム粉末にはTilop-45 (住友チ タニウム) を使用した。

この粉末は平均粒径が $30 \mu \mathrm{m}$ 程牢のガスアトマイズド粉末 であり，含有酸素量は 0.14 mass\% である. スペースホルダー には積水化製品工業で開発されたポリスチレンフォーム粉を 用いた.この粉末の平均粒径は $100 \mu \mathrm{m} ・$ タップ密度は $0.19 / \mathrm{cm}^{3}$ である. チタニウム粉末, ポリスチレンフォーム粉末の写真 をFig.1および2に示す.チタニウム粉末, ポリスチレンフォー ム粉末を混合し, PVAバインダーを加えてスラリーとする. さらに，嗍砂水溶液を添加してスラリーを粘土状のコンパウ ンドにする.これを任意の形状に成形, 乾燥してチタニウム 多孔質体の前躯体とする.ここでの成形にあたってはコンパ ウンドをローラーで圧延し，シート状にして乾燥させる。 ま たバルク体の作製に当ってはこのシート状のコンパウンドを 積層して作製した。

前躯体の顕微鏡写真をFig.3に示す.この前躯体を真空中で 加熱してPVA, ポリスチレン成分を分解し, 焼結してチタニウ ム多孔質体を作成する. チタニウムの焼結はモリブデン箱中 にセットしたジルコニアのサブストレート上で行い,箱内には スポンジチタンのゲッターを配置する。焼結温度は $1573 \mathrm{~K}$, 焼結時間は 1 時間とし, 焼結時の到達真空度は $10^{-2} \mathrm{~Pa}$ 程度で ある。

2.2 多孔質体作製のための実験条件

5 種類のスラリーをゲル化して作製したコンパウンド $\mathrm{A}, \mathrm{B}$, $\mathrm{C}, \mathrm{D}, \mathrm{E}$ 準備した.この 5 種類のコンパウンドはバインダー 中のチタニウム粉, およびスペースホルダーの量を変化させ て準備した. コンパウンド中の成分およびその分量をTable 1 に示した．表には同時に，焼結後の気孔率も示した．このコ
ンパウンドより引張試験片，および圧縮試験片を作製した。 引張試験片はコンパウンドを $1.5 \mathrm{~mm}$ の厚さに圧延して, 乾燥 させ，試験片形状に切り出して作製した．また，バルク状の コンパウンドをそのまま乾燥させると乾燥時の収縮により試 験片の変形や，場合によっては内部に空隙が生じる. そのた め, 圧縮試験片は乾燥させたシート状のコンパウンドの上に 未乾燥のシートを積層して乾燥するという操作を繰り返して 作製した. 試験片は積層方向により機械特性が異なると考え られるので, 積層方向に平行に圧縮する試験片と垂直に圧縮 する試験片の2 種類を準備した。 それぞれの試験片の寸法を Fig.4に示す．この寸法は焼結前の前躯体での寸法であり，焼 結後はこれより収縮した寸法となる。

\section{3 実験結果および検討}

3.1 焼結体の評価, および焼結時の収縮率

コンパウンドB〜Eの焼結体の断面写真をFig.5に示す. 断

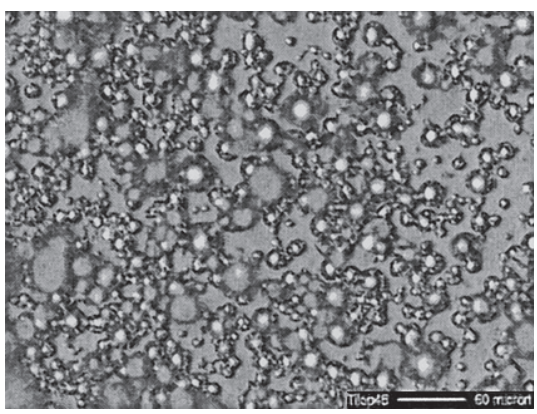

Fig.1 Titanium powder

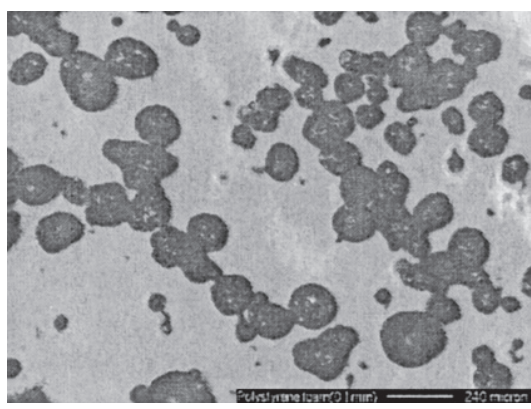

Fig.2 Polystyrene foam powder

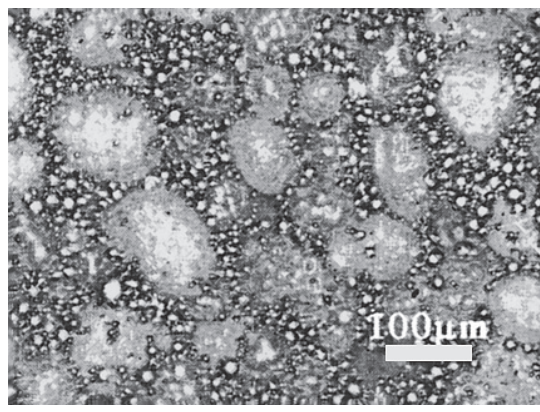

Fig.3 Photograph of precursor 
Table 1 Prepared compounds and their specifications

\begin{tabular}{|c|c|c|c|c|c|}
\hline & $\begin{array}{l}\text { Concentration } \\
\text { of Titanium } \\
\text { Powder / g }\end{array}$ & $\begin{array}{l}\text { Concentration } \\
\text { of } 6 \mathrm{wt} \% \\
\text { Aqueous } \quad \text { PVA } \\
\text { Solution / } \mathrm{ml}\end{array}$ & $\begin{array}{l}\text { Concentration } \\
\text { of Space } \\
\text { Holder / g }\end{array}$ & $\begin{array}{l}\text { Concentration } \\
\text { of } 8 \mathrm{wt} \% \\
\text { Aqueous Borax } \\
\text { Solution } / \mathrm{ml}\end{array}$ & $\begin{array}{l}\text { Porosity } \\
/ \%\end{array}$ \\
\hline$A$ & 140 & 25 & 0 & 5 & 17 \\
\hline B & 130 & 25 & 2 & 5 & 30 \\
\hline $\mathrm{C}$ & 120 & 25 & 5 & 5 & 50 \\
\hline $\mathrm{D}$ & 100 & 25 & 8 & 5 & 61 \\
\hline $\mathrm{E}$ & 60 & 25 & 12 & 5 & 77 \\
\hline
\end{tabular}

Tensile Test specimen

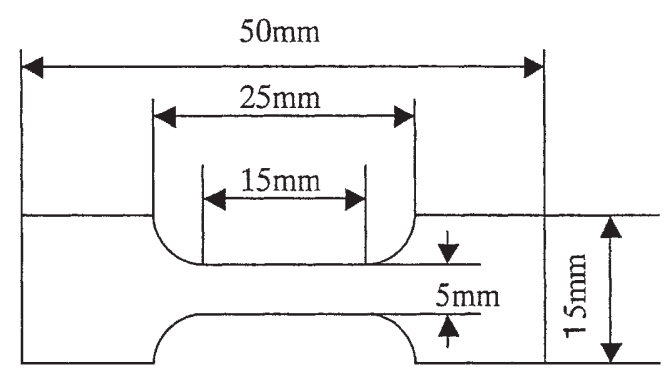

Thickness $1.5 \mathrm{~mm}$
Compression Test specimen

Compression directions

a)
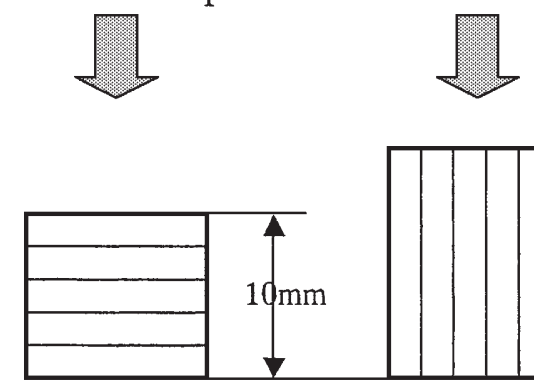

$10 \times 10 \mathrm{~mm}$

$10 \times 10 \mathrm{~mm}$

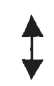

Laminating directions

Fig.4 Dimensions of tensile and compression test specimens

面写真よりコンパウンド C Eの焼結体ではオープンセル構 造をとることが確認でき,通気性を示すことがわかる.また， 焼結時の収縮率を Fig.6に示す. 収縮率はコンパウンド A か らDまで約 $17 \%$ とほぼ一定である.そのためこれらのコンパ ウンドを互いに組み合わせることが可能であり,焼結しても 収縮率に差がないためクラックを生じにくい.コンパウンド Eでは収縮がはげしくなり，これ以上コンパウンド中のス ペースホルダー量を増加しても $80 \%$ 以上の気孔率達成は難し い.

\section{2 機械特性}

引張試験は島津オートグラフ AGS-10kNDに油圧チャック を使用して行った。ひずみは試験片に貼り付けたひずみゲー ジにより計測した. 各焼結体の公称応力, 公称ひずみによる 応力ひずみ曲線を Fig.7に示す.また，この試験から得られ
たヤング率をFig.8に示す. 純チタニウムのヤング率は約 110 $\mathrm{MPa}$ であるが, 気孔率60\%まで急激に減少する.ヤング率は 気孔率 $50 \sim 60 \%$ で 30〜 $10 \mathrm{MPa}$ 程度となり, 骨と同程度のヤ ング率を持つこととなる.

圧縮試験は超硬アンビル間で端面を厚さ $0.1 \mathrm{~mm}$ のテフロン シートで潤滑して行った.圧縮は積層方向に平行な圧縮試験， 積層方向に垂直な圧縮試験の 2 種類を行った. 公称応力, 公 称ひずみによる応力ひずみ曲線をFig.9を示す.コンパウンド $\mathrm{A}, \mathrm{B}$ による試験片ではではプラト一領域に相当する領域は見 られない.コンパウンド C, D, Eよる試験片では応力の増加が なだらか, あるいは減少するプラトー領域が見られる.しか し，実際にはD, Eの試験片においては 10〜15\% 程度のひず みで大きな亀裂が発生し, その結果, 圧縮荷重が減少し始め る。 


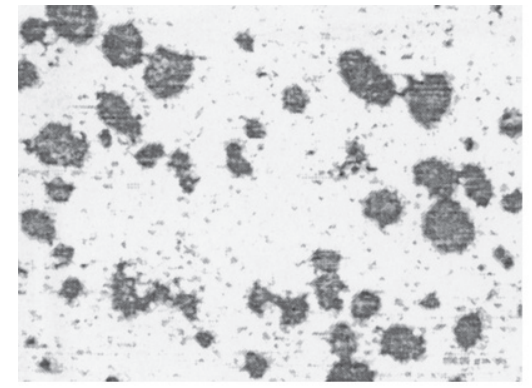

B: Porosity $=30 \%$



D: Porosity $=61 \%$

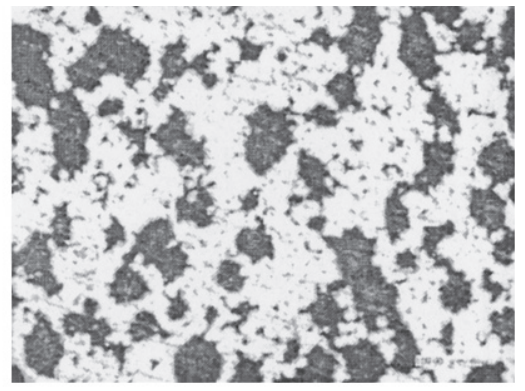

C: Porosity $=50 \%$

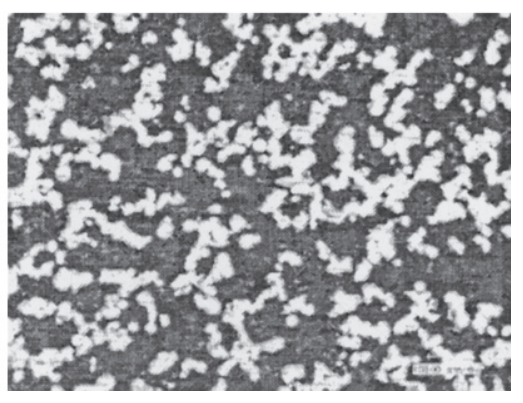

E: Porosity $=77 \%$

Fig.5 Cross-section photographs of porous titanium specimens

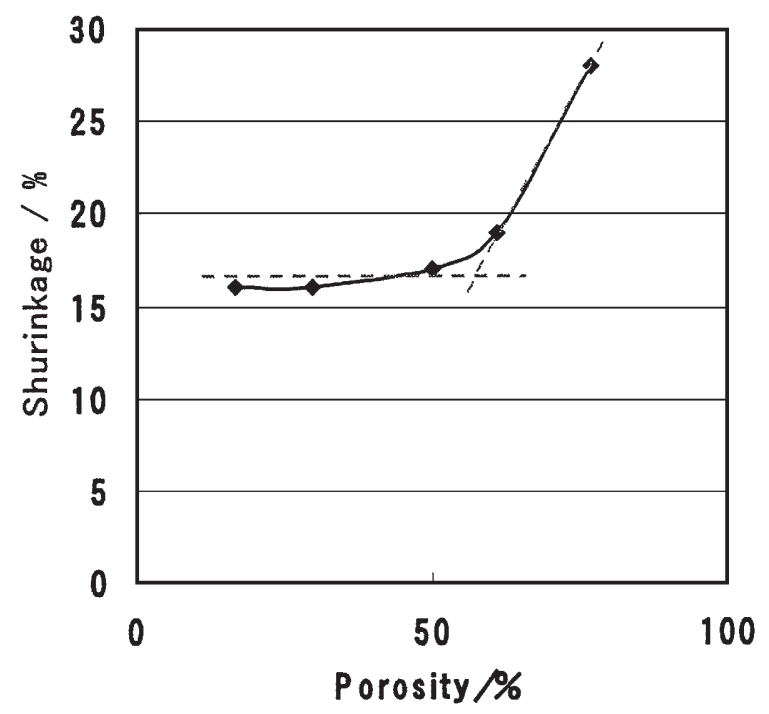

Fig.6 Shrinkage after sintering

密度と強度の関係をFig.10に示した. 引張試験による強度 は破断強度により評価した.多孔質体の圧縮強度はプラトー 応力で評価される場合が多い。しかし，気孔率が低いとプラ トー領域が観察されないため, そこでの圧縮試験による強度 評価は圧縮率 5\% での応力で評価した. 引張強度は気孔率が $50 \%$ から $60 \%$ と変化することにより $100 \mathrm{MPa}$ から $30 \mathrm{MPa}$ へ と大きく低下する.圧縮強度は積層方向に垂直に圧縮した場 合, ほぼ, 引張強度と同等であるが, 積層方向と平行に圧縮

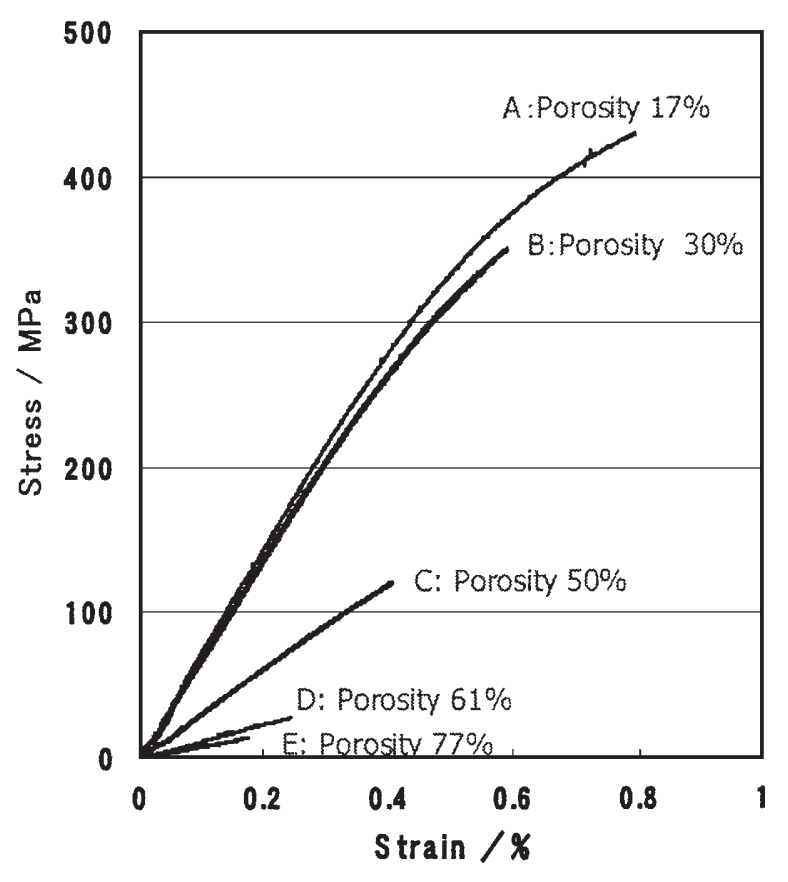

Fig.7 Stress strain curve by the tensile test

した場合, 引張強度より $100 \mathrm{MPa}$ 程度高い値となる. 気孔率 を 50〜 55\% 程度に設定すれば, ヤング率は $30 〜 20 \mathrm{GPa}$ 程度， 引張強度は100〜 70 MPa程度となると予想されインプラント 材としてきわめて良好な機械的性質を持つこととなる. 


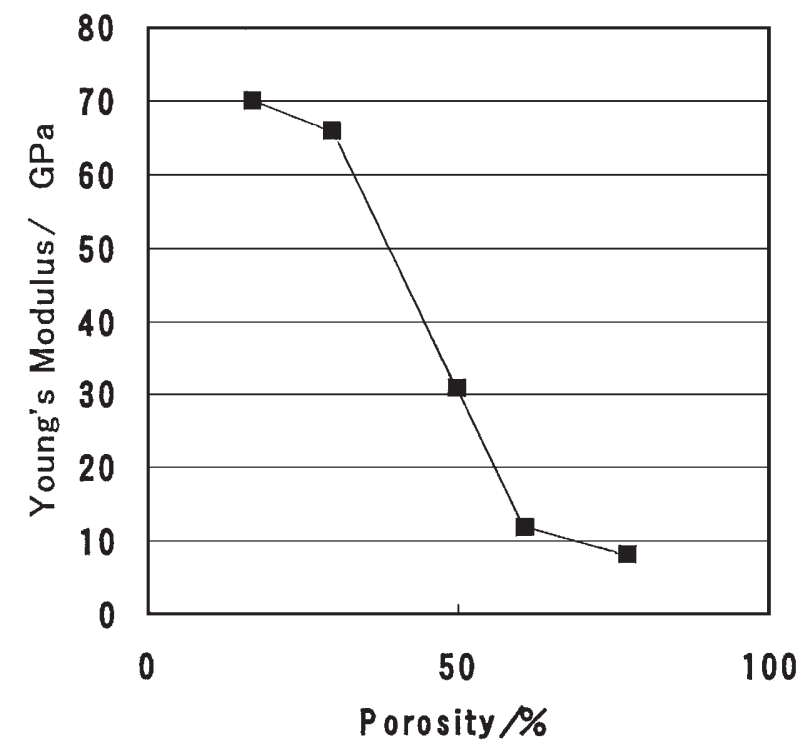

Fig.8 Young's moduli by the tensile test

\section{3 傾斜気孔率材料}

Fig.6に示したように,コンパウンドAからDにおいては焼 結時の収縮はほぼ一定である，そのため，これらのコンパウ ンドを任意に複合させることによって, 気孔率や強度に傾斜 をもたせた材料の構成が可能である.コンパウンド B と Dを 複合させた焼結体の例を Fig.11に示す。これらのコンパウン ドは粘土のように容易に加工できるため, 接合させることも 容易であり，ここでの前躯体も容易に準備できる.

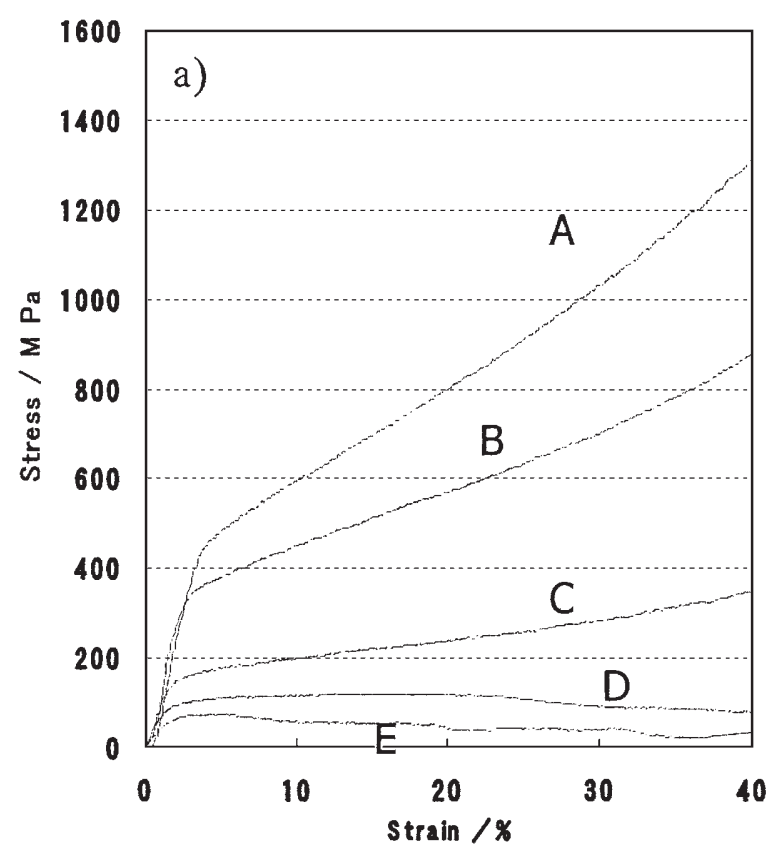

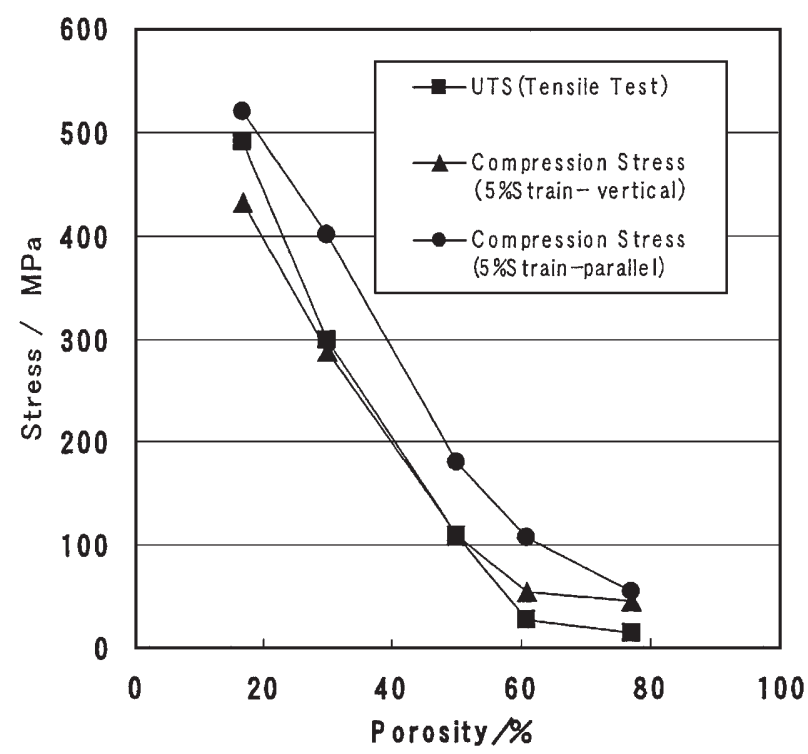

Fig.10 Relationship between porosity and stress.

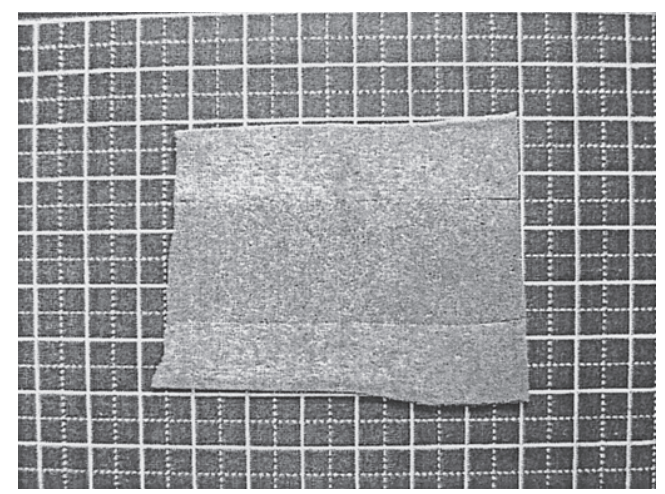

Fig.11 Graded-porosity-structure specimen.

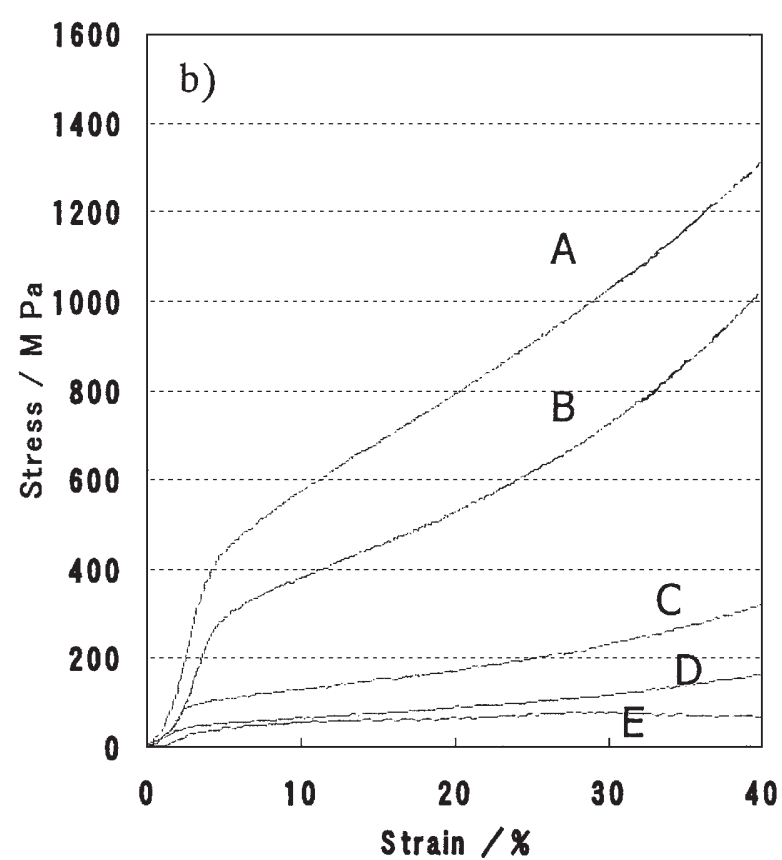

Fig.9 Stress strain curve by compression test

a) Compression direction is parallel to laminating direction b) Compression direction is vertical to laminating direction 


\section{4 結 論}

スペースホルダー法による粘土状のコンパウンドからの多 孔質金属作製手法を紹介し，その手法によりチタニウム多孔 質体の作製を試みた。また，その製品を，生体インプラント 材料としての応用をターゲットに評価を試みた。その結果， 気孔率を $55 \%$ 程度に設定する事により, ヤング率 $20 \mathrm{GPa}$, 引 張強度 $70 \mathrm{MPa}$, 圧縮強度 $100 \mathrm{MPa}$ 程度の多孔質体の作製でき ることが分かった。

すでに，多くのチタニウム多孔質体作製が試みられている ことは先にも述べているが,広い気孔率範囲において, 圧縮, 引張の双方から機械的特性評価を試みた例は少ない。しかし， 生体への実用化の観点からすれば現状の機械的特性の評価は 不十分であり,さらに絵合的な試験評価が行われなければな らない。また,ここで開発した手法は粘土のように成形，乾 燥のみで基本形状を与えることが可能である.チタニウム材 料は多孔質体であってもその成形加工は難しい。複雑形状が 要求されるインプラント部材の作製においては, 容易にネッ トシェイプが可能な本手法は極めて有効である.

\section{文献}

1) M.F.Assuby, A.G.Evans, N.A.Fleck, L.J.Gibson, J.W.Hutchinson and H.N G.Wadley: Metal Foams, A Design Guide, Butterworth-Heineman, (2000).

2) J.Banhart: "Manufacture characterization and application of cellular metals and metal foams", Progress in Materials Science, 46(2001)599-632.

3) T.Shimizu and K.Matsuzaki: "New method to produce foam metals using water base binder", J. Jpn. Soc. Powder Metallurgy, 50(2001)177-181.

4) T.Shimizu and K.Matsuzaki: "Foam metal production process using water base binder and wax emulsion", Proceedings of MetFoam 2003, J.Banhart, N.A.Fleck and A.Mortensen ed., Berlin, Verlag MIT Publishing, (2003)253-256.
5) Y.Okazaki, E.Nishimura, H.Nakada and K.Kobayashi: "Surface analysis of $\mathrm{Ti}-15 \mathrm{Zr}-4 \mathrm{Nb}-4 \mathrm{Ta}$ alloy after implantation", Biomaterials, 22(2001)599-607.

6) M.Long and H.J.Rack: "Titanium Alloys in Total Joint Replacement-A Materials Science Perspective", Biomaterials, 19(1998) 1621-1639.

7) S.Fujibayashi, M.Neo, H.M.Kim, T.Kokubo and T.Nakamura: "Osteoinduction of Porous Bioactive Titanium Metal", Biomaterials, 25(2004)443-450.

8) I.H.Oh, N.Nomura, N.Masahashi and S.Hanada: "Mechanical properties of porous titanium compacts prepared by powder sintering", Scripta Materialia, 49(2003)1197-1202.

9) D.C.Dunand: "Processing of titanium foams", Advanced Engineering Materials, 6(2004)369-376.

10) N.Nomura, T.Kohama, I.H.Oh, S.Hanada, A.Chiba, M.Kanehira and K.Sasaki: "Mechanical properties of porous Ti-15M0-5Zr-3A1 compacts prepared by powder sintering", Materials Science and Engineering C, 25(2005)330-335.

11) C.E.Wen, M.Mabuchi, Y.Yamada, K.Shimojima, Y.Chino and T.Asahina: "Processing of biocompatible porous $\mathrm{Ti}$ and Mg", Scripta Materialia, 45(2001)1147-1153.

12) C.E.Wen, Y.Yamada, K.Shimojima, Y.Chino, H.Hosokawa and M.Mabuchi: "Novel titanium foam for bone tissue engineering", J. Mater. Res., 17(2002)2633-2639.

13) L.Laptev, M.Bram, H.P.Buchkremer and D.Stover: "Study of production route for titanium parts combining very high Porosity and complex shape", Powder.Metallurgy, 47(2005)85-92.

14) M.Watase and K.Nishinari: "Large deformation of hydro gels of poly(vinylalcohol), agarose and kappa-corrageenan", Macromol. Chem. Phys., 186(1985)1081-1086.

15) H.Ochiai, S.Fukushima, M.Fujikawa and H.Yamamura: "Mechanical and Thermal Properties of Poly(vinyl alcohol) Cross linked by Borax", Polymer Journal, 8(1976)131-133. 